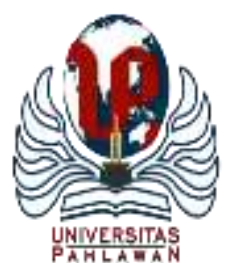

\title{
JURNALBASICEDU
}

Volume 5 Nomor 6 Tahun 2021 Halaman 5266 - 5274

Research \&Learningin Elementary Education

https://jbasic.org/index.php/basicedu

\section{Peran Pendidikan Kewarganegaraan dalam Mewujudkan Sekolah Damai di Tengah-Tengah} Kehidupan Masyarakat Pluralis

\section{Aulia Nur Jannah ${ }^{1 凶}$, Putri Salma ${ }^{2}$, Rachmi Nursifa Yahya ${ }^{3}$, Dinie Anggraeni Dewi ${ }^{4}$, Yayang Furi Furnamasari ${ }^{5}$ \\ Jurusan Pendidikan Guru Sekolah Dasar, Universitas Pendidikan Indonesia Kampus Cibiru, Indonesia $a^{1,2,3,4,5}$ E-mail: aulianurjannah@upi.edu ${ }^{1}, \underline{\text { putrisalma.n@upi.edu }}^{2}$, rachminursifayahya@upi.edu $^{3}$, dinieanggraenidewi@upi.edu ${ }^{4},{\text { furi2810@ } \text { upi.edu }^{5}}^{5}$}

\begin{abstract}
Abstrak
Pendidikan kewarganegaraan dalam mewujudkan sekolah damai di tengah kehidupan masyarakat pluralis menjadikan suatu tantangan dan keberagaman dalam kehidupan yang diharapkan suatu bangsa dapatmewujudkan sikap saling menghargai dan memiliki keharmonisan hidup tanpa adanya konflik sosial dalam masyarakat yang pluralis. Tulisan ini bertujuan untuk membentuk karakter dan membangun kesadaran para generasi muda khususnya para siswa dan siswi dalam berbangsa dan bernegara di Sekolah. Peneliti menggunakan pendekatan kualitatif dan metode deskriptif sebagai gambaran untuk memperoleh hasil penelitian. Hasil penelitian menunjukkan bahwa peran pendidikan kewarganegaraan memiliki peranan yang penting dalam mewujudkan sekolah damai. Menurut Suyanto dalam Zulnuraini pendidikan kewarganegaraan merupakan pendidikan karakter yang tinggi di dalam kelas budi pekerti yang melibatkan tiga aktivitas yaitu kognitif (cognitive), perasaan (feeling), dan tindakan (action) dalam membangun serta menumbuhkan karakter yang baik untuk menjalankan kehidupan dalam bermasyarakat.
\end{abstract}

Kata Kunci: Peran pendidikan kewarganegaraan, toleransi, dan masyarakat pluralis.

Abstract

Civic education in realizing peaceful schools amid pluralist society makes a challenge and diversity in the life that a nation hopes can learn mutual respect and harmony in life without social conflict in a pluralist society. This paper aims to form character and build awareness of the younger generation, especially students and students in the nation and state in the School. Researchers use qualitative approaches and descriptive methods as an overview to obtain research results. The results showed that the role of civic education has an important role in realizing peaceful schools. According to Suyanto in Zulnuraini, civic education is high character education in the ethics class that involves three activities, namely cognitive (cognitive), feeling (feeling), and action (action), in building and fostering good character to run life in society.

Keywords:The role of civic education, tolerance, and pluralist societies.

Copyright (c) 2021 Aulia Nur Jannah, Putri Salma N, Rachmi Nursifa Yahya, Dinie Anggraeni Dewi, Yayang Furi Furnamasari

$\triangle$ Corresponding author :

Email : aulianurjannah@upi.edu

DOI $\quad$ https://doi.org/10.31004/basicedu.v5i6.1604

ISSN 2580-3735 (Media Cetak)

ISSN 2580-1147 (Media Online) 
5267 Peran Pendidikan Kewarganegaraan dalam Mewujudkan Sekolah Damai di Tengah-Tengah Kehidupan Masyarakat Pluralis - Aulia Nur Jannah, Putri Salma N, Rachmi Nursifa Yahya, Dinie Anggraeni Dewi, Yayang Furi Furnamasari

DOI: https://doi.org/10.31004/basicedu.v5i6.1604

\section{PENDAHULUAN}

Pendidikan kewarganegaraan dipelajari dan direalisasikan dalam kehidupan sehari-hari diseluruh belahan dunia, walaupun memang memiliki beberapa istilah seperti civic education, citizenship education ataupun democracy education (Kaelan dan Zubaidi, 2010). Namun apapun istilah dalam pendidikan kewarganegaraan, tentu memiliki peranan penting yang sama yakni dalam menegakkan nilai pandangan atau pemikiran yang terdapat di dalam Pancasila. Salah satunya yaitu mengenai nilai-nilai dasar kemanusiaan dan keadilan.

Tujuan mata Pelajaran Pendidikan kewarganegaraan adalah untuk mengajarkan pesera didik menjadi waraga negara yang sesuai dengan kaidah-kaidah pancasila seperti bertanggung jawab, santun, percaya diri dalam berkomunikasi baik dirumah maupun lingkungan sosial lainnya (Supriyanto, 2018). Oleh karena itu, berdasarkan tujuan di atas maka mata pelajaran pendidikan kewarganegaraan merupakan sarana dalam pembentukan karakter generasi penerus bangsa.

Menurut Suharyanto (Suharyanto, 2013), siswa diharapkan memiliki sikap saling menghormati, saling menghargai dan saling toleransi dengan setiap perbedaan, hal tersebut dapat diupayakan melalui pendidikan kewarganegaraan. Karena pendidikan kewarganegaraan mempunyai kaitan dengan sebuah kerukunan, maka adanya mata pelajaran ini diharapkan peserta didik mampu memiliki kesadaran dan keinginan bertingkah laku sesuai dengan norma yang ada. Sehingga dalam ruang lingkup sekolah dapat terjalin sebuah toleransi dan terciptalah sekolah damai.

Toleransi merupakan suatu bentuk saling menghormati sesama dan tidak memaksakan suatu kehendak. Apabila seseorang memiliki sikap yang menganggap dirinya lebih tinggi, lebih baik dari pada yang lain, cenderung akan mengakibatkan sikap kurang baik yakni anti toleran yang justru merupakan sebuah cikal bakal perpecahan (Murniyetti, dkk, 2016). Toleransi adalah prasyarat nyata dalam merealisasikan setiap nilai pada pancasila dengan sungguh-sungguh serta menjaga ikatan yang baik dengan sesama warga negara Indonesia. Toleransi di lingkungan sekolah berarti menjaga hubungan baik dengan semua warga di sekolah baik dari segi sosial, agama, budaya, dan lain sebagainya. Dengan adanya sikap toleransi ini, maka akan terciptalah sikap saling menghormati yang melahirkan suasana damai dan terjaganya persatuan dan kesatuan.Untuk menumbuhkan sikap toleransi di kalangan siswa, perlu upaya pendidikan untuk menanamkan nilai-nilai tersebut, oleh sebab itu mata pelajaran pendidikan kewaragenagaraan tidak hanya mencakup aspek intelektual saja tetapi juga aspek nilai dan aspek psikomotorik sehingga disinin tenaga pendidik memiliki tanggung jawab lebih dalam membantu terealisasinya aspek-aspek tersebut. Selain dengan adanya sikap toleransi, multikulturalisme juga dapat berupaya dalam meminimalisir suatu konflik atau perbedaan. Untuk dapat hidup rukun dalam keberagaman maka diperlukan pendekatan multikultural. Penanaman nilai-nilai multikultural dapat menghalau suatu konflik, dengan adanya nilai-nilai multikultutal ini memberikan wawasan untuk mengetahui perbedaan atau keberagaman dan sikap toleransi (Widiyanto, 2017).

Nilai-nilai multikultural diterapkan dalam pendidikan. Adapun pembelajarannya dengan memberikan pemahaman mengenai keanekaragaman sehingga dapat menimbulkan sikap toleransi. Hal terseebut tentu erat kaitannya dengan kegiatan pembelajaran pada mata pelajaran pendidikan kewarganegaraan.Oleh karena itu, tujuan dibuatnya artikel ini adalah untuk melihat dan menganalisis peran pendidikan kewarganegaraan dalam mewujudkan sekolah damai di tengah-tengah kehidupan masyarakat pluralis. Hal tersebut dikarenakan pendidikan kewarganegaraan mempunyai peranan dasar dalam menciptakan kedamaian dalam keanekaragaman kultur di Indonesia. 
5268 Peran Pendidikan Kewarganegaraan dalam Mewujudkan Sekolah Damai di Tengah-Tengah Kehidupan Masyarakat Pluralis - Aulia Nur Jannah, Putri Salma N, Rachmi Nursifa Yahya, Dinie Anggraeni Dewi, Yayang Furi Furnamasari

DOI: https://doi.org/10.31004/basicedu.v5i6.1604

\section{METODE PENELITIAN}

Penelitian ini menggunakan pendekatan kualitatif dan metode deskriptif (Gunawan, I, 2013). Sarana dalam penelitian ini merupakan peneliti sendiri yang bertindak sebagai human instrument dengan cara memfokuskan mencari sumber teori setelah itu menganalisa teori serta data-data yang sudah diperoleh dan dirangkum dalam sebuah kesimpulan yang berdasar pada hasil teori dan data tersebut. Sedangkan sumber teorinya didapat dari hasil studi kepustakaan dari beberapa referensi seperti buku, jurnal maupun artikel yang memiliki kesinambungan dengan pembahasan mengenai peran pendidikan kewarganegaraan dalam mewujudkan sekolah damai di tengah-tengah kehidupan masyarakat pluralis.

\section{HASIL DAN PEMBAHASAN}

Negara dengan komposisi masyarakat pluralis salah satunya diduduki oleh Indonesia. Indonesia disebut sebagai negara pluralis karena di dalamnya sudah memiliki pemahaman adanya sikap menghargai perbedaan dalam satu masyarakat dan membebaskan berbagai kelompok yang heterogen untuk tetap menjaga keunikan setiap ciri khas dan budayanya masing-masing. Bagi Indonesia, membangun masyarakat yang demokratis di tengah-tengah masyarakat yang heterogen tentu bukan lah hal yang mudah. Mewujudkan masyarakat Indonesia yang pluralis perlu adanya pendidikan pluralisme agar setiap masyarakat Indonesia tetap menjunjung tinggi cinta damai sehingga tidak terjadi perpecah belahan antar suku, budaya, maupun wilayah. Pendidikan pluralisme dapat diartikan sebagai suatu pendidikan dengan nuansa damai, terbebas dari berbagai prasangka buruk, memiliki kebebasan untuk mengeksplor sesuatu, serta memiliki rasa kebebasan untuk belajar atau yang sekarang sering disebut sebagai merdeka belajar dari berbagai budaya dan etnis dalam perspektif yang beragam di tengah-tengah masyarakat yang multikultural (Parekh, 2017).

Indonesia dalam membangun dan menciptakan masyarakat yang berbeda dan sama-sama mengerjakan aktifitas social atau yang sering disebut sebagai multi etnis dan budaya tentu memiliki berbagai tuntutan. Tuntutan-tuntutan tersebut salah satunya adalah seperti terbentuknya suatu pandangan baru mengenai nasionalisme Indonesia, maksudnya adalah muncul sebuah pemahaman baru yang menciptakan dan mempertahankan kedaulatan, persatuan dan kesatuan sebuah negara yang menunjukkan identitas serta tujuan yang dibangun bersama. Khususnya di era reformasi sejak kebangkitan nasionalis, nasionalisme Indonesia telah mengalami perombakan konsep dalam perkembangannya, seperti diminta untuk membuat rumusan baru mengenai nasionalisme Indonesia dalam membangun suatu nation state yang multikultural yang dikhususkan dalam pengimplementasian pendidikan nasional. Pandangan baru tersebut tentu memerlukan dukungan dari masyarakat Indonesia yang cerdas dan bermoral, karena masyarakat pluralistis dan multikultural tidak mungkin dapat terbentuk tanpa adanya masyarakat yang cerdas dan bermoral (Hanum, 2012).

Pendidikan pluralisme lebih menekankan kegiatan untuk tercapainya sekolah damai. Menurut pendiri perdamaian, Johan Galtung dalam (Mahnan Marbawi, Setiyo Iswoyo Husni Mubarok, 2020), beliau membahas mengenai konsep damai, bahwa damai menurut beliau adalah ketika kekerasan tidak ada. Maka, selama masih ada kekerasan, menurutnya belum tercipta suatu kedamaian. Selain itu, Galtung menyebutkan ada dua jenis kekerasa, yaitu: (1) Kekereasan Langsung (Direct Violence), yaitu segala bentuk kekerasan yang bersifat kasat mata dan mampu melibatkan fisik, harta benda, jiwa, maupun raga seseorang seperti pemukulan, pemerkosaan, pembunuhan, dan lain sebaginya. (2) Kekerasan tidak langsung (Indirect Violence), yaitu kekerasan yang bersifat tidak kasat mata, tidak tampak namun tetap terasa. Kekerasan tidak langsung ini terkesan tidak disadari karena tidak terlihat oleh penglihatan dan tanpa melalui proses sebab akibat secara langsung dan memerlukan waktu dalam proses penelusuran hingga diketahui penyebabnya. Kekerasan tidak langsung dalam rumusan Galtung terdiri dari dua jenis kekerasan yaitu kejahatan struktural dna kultural. 
5269 Peran Pendidikan Kewarganegaraan dalam Mewujudkan Sekolah Damai di Tengah-Tengah Kehidupan Masyarakat Pluralis - Aulia Nur Jannah, Putri Salma N, Rachmi Nursifa Yahya, Dinie Anggraeni Dewi, Yayang Furi Furnamasari

DOI: https://doi.org/10.31004/basicedu.v5i6.1604

Berbagai upaya dalam mengatasi kekerasan fisik disebut sebut sebagai perdamaian negatif, hal ini karena kekerasan jenis ini melibatkan senjata dalam pencegahannya. Cipta damai (peace making) dan jaga damai (peace keeping) termasuk ke dalam perdamaian negatif yang biasa digunakan sebagai bentuk pengelakan dari kekerasan langsung. Sementara itu, untuk menanggulangi kekerasan non fisik atau yang dalam hal ini terbagi menjadi kekerasan struktural dan kultural dikenal dengan perdamaian positif. Perdamaian jenis ini berhubungan dengan keadilan sosial yang bersifat jangka panjang. Bina damai (peace building) biasanya melekat pada perdamian jenis ini. Maka, damai adalah segala situasi ketika kekerasan fisik dan kekerasan struktural maupun kekerasan kultural lenyap.

\section{Gambar 1 Kerangka Perdamaian Positif dan Perdamaian Negatif KEIKERASAN}

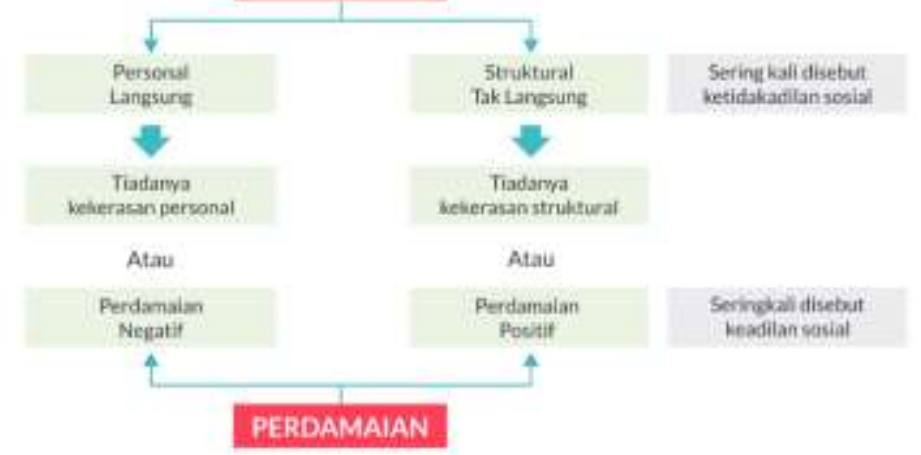

Berbagai upaya dilakukan oleh Indonesia untuk menertibkan masyarakat yang pluralisme dan multikultural, salah satunya adalah pemberdayaan sekolah damai. Sekolah damai memiliki tujuan yaitu untuk menciptakan lingkungan sekolah yang memungkinkan untuk semua komponennya menjadi duta damai di luar. Maksud dari sekolah damai disini bukan hanya berarti batas-batas bangunan fisik, melainkan juga ruang imajiner yang mendapatkan dukungan dari berbagai pihak untuk terlaksananya budaya damai di sekolah. Pada akhirnya, untuk mencapai kemaksimalan sekolah damai diperlukan seluruh komponen yang ada di sekolah seperti peserta didik atau siswa, pendidik atau guru, tenaga kependidikan seperti staff TU beserta jajarannya, serta hal-hal lain yang menjadi teladan dan duta perdamaian baik di dalam maupun di luar sekolah.

\section{Sekolah Damai di Indonesia}

Dalam rangka merespons situasi kehidupan sosial keagamaan terbaru yang cenderung kurang toleran, sikap permisif pada kekerasan, dan diskriminasi kelompok minoritas, maka hal tersebut membuat inisiatif dalam mengembangkan pendidikan perdamaian. Disadari atau tidak, praktik intoleransi bukan hanya sebagai narasi besar melainkan sudah terjadi dalam kehidupan sehari-hari termasuk di dalam sekolah (Hamid, 2018). Berbagai masukan dari penggerak bangsa untuk melaksanakan pendidikan perdamaian melalui sekolah damai adalah karena sebuah keyakinan sebagai upaya untuk memutus mata rantai intoleransi, lebih luas dari itu yaitu untuk mencegah ekstremisme kekerasan. Terdapat lima fokus kebijakan sekolah damai, diantaranya : 

Kehidupan Masyarakat Pluralis - Aulia Nur Jannah, Putri Salma N, Rachmi Nursifa Yahya, Dinie Anggraeni Dewi, Yayang Furi Furnamasari

DOI: https://doi.org/10.31004/basicedu.v5i6.1604

\section{Gambar 2 Fokus Pilar Kebijakan Sekolah Damai}

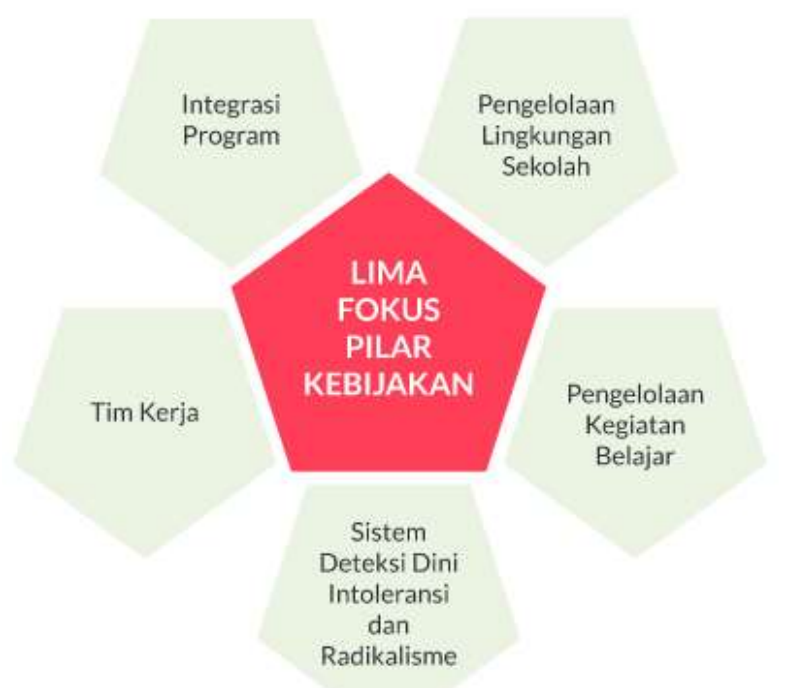

Pertama, kebijakan yang mengatur peran serta fungsi tim pelaksana dan tim pengembangan sekolah damai. Contoh kebijakan yaitu seperti Surat Keputusan (SK) Kepala Sekolah Terkait Satuan Tugas (Satgas) Sekolah Damai. Surat Keputusan sekurang-kurangnya berisi perumusan landasan, tujuan, kewenangan, tugas pelaksana Sekolah Damai, dan anggaran. Kedua, kebijakan yang berisi integrasi Program Sekolah Damai dalam kebijakan sekolah seperti Surat Keputusan (SK) Kebijakan Program Sekolah Damai yang dicantumkan dalam kurikulum Tingkat Satuan Pendidikan (KTSP), terutama pada rumusan Visi, Misi, Tujuan, Silabus dan RPP. Ketiga, kebijakan berisi pengelolaan lingkungan sekolah terkait Sekolah Damai seperti Surat Keputusan (SK) Pengembangan Lingkungan Sekolah Damai. Keempat, Kebijakan berisi pengelolaan kegiatan pembelajaran di kelas yang menguatkan Program Sekolah Damai seperti Surat Keputusan (SK) Pengelolaan Kegiatan Pembelajaran Kelas Sekolah Damai. Bagian yang juga menjadi fokus adalah lahirnya sistem yang membekali pihak sekolah untuk lebih sadar terhadap gejala yang meningkatkan tantangan bagi toleransi dan perdamaian. Terakhir, yaitu kebijakan berisi sistem deteksi dini intoleransi dan radikalisme.

\section{Peran Pendidikan Kewarganegaraan Untuk Menciptakan Sekolah Damai}

Pendidikan kewarganegaraan memiliki peran dalam menciptakan karakter siswa untuk mewujudkan sekolah damai. Menurut Suyanto dalam Zulnuraini (Zulnuraini, 2012), beliau menyatakan bahwa pendidikan karakter disebut juga sebagai pendidikan tinggi kelas budi pekerti yang melibatkan setidaknya tiga aktivitas, yaitu kognitif (cognitive), perasaan (feeling), dan tindakan (action). Menurut (Putri, Ragil Dian Purnama, 2018), terdapat hal-hal yang dapat diimplementasikan oleh pendidik atau guru agar dapat menunjang beberapa komponen dari karakter cinta damai, yaitu (1) Mengubah suasana belajar menjadi lebih nyaman, tentram, dan harmonis, (2) Membuat kreasi papan bimbingan yang berisikan slogan-slogan anti kekerasan di selasar lorong kelas, (3) Memupuk persahabatan dan keakraban antar siswa melalui kegiatan makan bareng ketika jam istirahat, (4) Membiasakan untuk menerapkan perilaku anti bullying terhadap siswa, pendidik, maupun tenaga kependidikan, (5) Menerapkan peraturan, tata tertib, juga sanksi yang tegas terhadap suatu perilaku kekerasan serta pelecehan yang terjadi di sekolah.

Sebagaimana yang kita ketahui bahwasannya sekolah merupakan suatu sistem sosial masyarakat, di mana para siswa berkumpul saling belajar untuk berinteraksi, belajar memahami dan menerapkan normanorma sosial yang berlaku khsusnya yang berlaku di sekolah, belajar bekerja sama, belajar menghargai serta berlajar berbagai aspek kehidupan sebagaimana layaknya yang terjadi dalam kehidupan nyata di masyarakat. 
5271 Peran Pendidikan Kewarganegaraan dalam Mewujudkan Sekolah Damai di Tengah-Tengah Kehidupan Masyarakat Pluralis - Aulia Nur Jannah, Putri Salma N, Rachmi Nursifa Yahya, Dinie Anggraeni Dewi, Yayang Furi Furnamasari

DOI: https://doi.org/10.31004/basicedu.v5i6.1604

Maka sudah jelas bahwa memang setiap anak dikaruniai benih untuk bergaul, saling berkomunikasi yang pada hakekatnya mengandung unsur saling memberi dan menerima (Tirtarahardja, 1994). Semua kegiatan yang pada dasarnya merupakan hakekat manusia itu dilakukan terhadap berbagai aspek kehidupan dalam lingkungan sekolah yang tujuannya tiadak lain sebagai bekal bagi siswa agar lebih memiliki kesiapan dalam memasuki lingkungan masyarakat terutama setelah tamat pada jenjang pendidikan tertentu.

Menurut pemahaman secara universal, pendidikan dapat dilaksanakan secara formal, informal, maupun non formal. Maka dari itu, pendekatannya pun memiliki beberagam cara seperti pendekatan perorangan (Personal Approach), pendekatan kelompok (Interpersonal Approach), dan pendekatan klasikal (classical approach) (Sumaatmadja, 1990).

Pendidikan Kewarganegaraan hadir sebagai upaya penguatan sikap toleran di tengah-tengah masyarakat yang multikultural. Pendidikan kewarganegaraan muncul sebagai pembelajaran konstruktivisme dengan strategi top down processing yang artinya belajar dari pengambilan masalah-masalah kompleks yang tujuannya untuk dipecahkan bersama (Baharudin, Wahyuni, 2010). Penemuan permasalahan yang kompleks ini berperan sebagai bahan awal kajian pembelajaran untuk membentuk keterampilan atau sikap toleransi dan keragaman. Melalui pembelajaran konstruktivisme menjadi teori belajar yang digunakan dalam pendidikan multikulturalisme dengan tantangan global yang beragam terjadi saat ini (Halim dan Mislinawati, 2019).

Unsur utama pembelajaran yang sangat penting adalah desain pembelajaran. Kualitas hasil dari pembelajaran merupakan produk yang dihasilkan ketika strategi atau desain pembelajaran dirancang dengan baik pula, karena tujuan dari mengajar adalah membuat hasil belajar dapat tercapai sesuai dengan tujuan yang semestinya (Munthe, 2010).

Dalam praktiknya, Pendidikan Kewarganegaraan yang diajarkan oleh guru kepada siswa sudah memuat peranan baik dalam tumbuh kembang karakter siswa sebagai generasi penerus bangsa. Dengan adanya mata pelajaran pendidikan kewarganegaraan, maka secara tidak langsung guru telah mendidik anak untuk cinta terhadap tanah air dengan menjalankan berbagai upaya untuk tetap menjaga persatuan dan kesatuan (Izma, T. Yolanda, 2019). Seperti halnya sikap sopan santu merupakan sebuah karakter yang ditanamkan dalam pembelajaran pendidikan kewarganegaraan dan sudah mampu mencirikan karakter baik bangsa Indonesia. Dalam upaya pemaksimaan karakter anak usia sekolah dasar diperlukan adanya peolahan atau perencanaan penyajian materi pendidikan kewarganegaraan yang dilakukan oleh guru kelas agar dalam proses penyampaian materi dapat tersampaikan secara efektif dan efisien yang imbasnya manfaat dari pembelajaran pendidikan kewarganegaraan dapat dirasakan oleh guru maupun siswa.

Menurut Amala dan Dini (Amala Sundari, 2021), proses pembelajaran pendidikan kewarganegaraan harus mampu memberdayakan serta membudayakan setiap peserta didik. Artinya adalah bahwa setiap proses dan hasil pendidikan harus mampu memfasilitasi peserta didik untuk melakukan proses belajar dalam memperluas wawasan (learning to know), membangun kemampuan untuk melakukan sesuatu (learning to do), belajar untuk hidup dan melakuakn kehidupan (learning to be), dan belajar untuk hidup bernegara (learning to live together).

Pemberdayaan msyarakat atau biasa disebut sebagai active citizenship melalui kajian kewarganegaraan salah satu tujuannya ditujukan untuk pembentukan masyarakat yang demokratis. Active Citizenship didefinisikan oleh komisi di Eropa sebagai pemberdayaan seseorang yang memungkinkan mereka memiliki rasa nyaman dalam budaya demokratis dan merasa bahwa mereka dapat membuat berbagai perbedaan dalam komunitas yang sedang dijalani (Bilqis, dkk, 2019). Setiap orang (Citizen) memiliki keaktifan dalam komunitas masing-masing dengan berbagai cara, seperti ada yang memiliki untuk memiliki keterlibatan langsung untuk mempengaruhi kehidupan mereka pada tingkatan lokal, sementara ada juga yang ingin melakukan sesuatu untuk membuat perbedaan pada penyebab yang memiliki dampak secara global atau menyeluruh (Aulia, Syifa Siti, 2019). 
5272 Peran Pendidikan Kewarganegaraan dalam Mewujudkan Sekolah Damai di Tengah-Tengah Kehidupan Masyarakat Pluralis - Aulia Nur Jannah, Putri Salma N, Rachmi Nursifa Yahya, Dinie Anggraeni Dewi, Yayang Furi Furnamasari

DOI: https://doi.org/10.31004/basicedu.v5i6.1604

Bukan hanya mata pelajaran pendidikan kewrganegaraan saja yang memiliki peran penting dalam pendidikan masyarakat Indonesia yang multikulturalis, tetapi guru pendidikan kewarganegaraan pun demikian. Guru pendidikan kewarganegaraan mengajarkan banyak hal seperti macam-macam nilai, macammacam moral, macam-macam norma, dan berbagai perilaku yang mencerminkan warga negara yang baik. Guru pendidikan kewarganegaraan pun mengajarkan nilai-nilai yang terkandung dalam setiap pancasila seperti nilai ketuhanan dan persatuan, karena sebagaimana yang kita ketahui bahwa Indonesia memiliki beragam suku, agama, ras, dan lain sebagainya. Maka, perlu adanya sikap toleransi atau saling menghargai satu dengan lainnya. Menurut Sofian Abdulatif dan Dinie Anggraeni (Sofian Abdulatif, 2021), guru pendidikan kewarganegaraan dituntut untuk memiliki kemahiran dalam mengurangi atau bahkan menghilangkan keunggulan apda satu golongan, suku, etnis, agama, dan budaya tertentu. Hal ini dilakukan sebagai upaya untuk mewujudkan dan menegakkan keadilan dan digunakan pula sebagai pendekatan untuk membentuk kepribadian siswa terutama dalam memupuk toleransi dan saling menghargai antar teman sebaya.

Terapat suatu teori yang memiliki keterkaitan dengan sikap toleransi siswa, yaitu teori Albert Bandura. Berdasarkan teori yang dikemukakan oleh beliau, terbentuknya sikap toleransi adalah melalui proses dan tahapan seseorang ketika menerima informasi yang berasal dari lingkungan sekitar yang paling dekat dengan dirinya. Sikap toleransi tidak muncul dengan sendirinya, namun sikap toleransi itu tumbuh melalui tahapan tertentu dengan didorong dengan hakekat awal bahwasannya manusia sudah dikaruniai akal sehat berupa pikiran yang difungsikan untuk berfikir, mengingat, menilai sesuatu, dan mampu untuk membandingkan sehingga pada akhirnya mampu mengambil keputusan yang dianggapnya terbaik. Sehingga dari sini lah awal terbentuknya manusia yang baik atau bahkan sebaliknya yang dalam hal ini mengarah kepada sikap toleransi pada siswa (Sofian Abdulatif, 2021).

\section{KESIMPULAN}

Pendidikan pluralisme diartikan sebagai suatu pendidikan yang memiliki nuansa damai, yakni terbebas dari berbagai prasangka buruk, memiliki kebebasan untuk mengungkapkan sesuatu hal, serta memiliki rasa kebebasan untuk belajar dari berbagai budaya dan etnis dalam perspektif yang beragam di tengah-tengah masyarakat yang multikultural. Pendidikan pluralisme ini lebih menekankan kegiatan untuk tercapainya sekolah damai. Pada akhirnya, untuk mencapai kemaksimalan sekolah damai ini sangat diharuskan untuk seluruh komponen sekolah mulai dari peserta didik, pendidik, tenaga kependidikan, serta lainnya untuk menjadi teladan dan duta perdamaian di dalam maupun di luar sekolah. Pendidikan perdamaian melalui sekolah damai ini adalah sebab sebuah keyakinan sebagai upaya untuk memutus mata rantai intoleransi, lebih luas dari itu yaitu untuk mencegah ekstremisme kekerasan.

Menurut (Aji, 2018) terdapat beberapa hal dalam membentuk karakter cinta damai, yaitu (1) Mengubah suasana belajar menjadi lebih nyaman, tentram, dan harmonis, (2) Membuat kreasi papan bimbingan yang berisikan slogan-slogan anti kekerasan di selasar lorong kelas, (3) Memupuk persahabatan dan keakraban antar siswa melalui kegiatan makan bareng ketika jam istirahat, (4) Membiasakan untuk menerapkan perilaku anti bullying terhadap siswa, pendidik, maupun tenaga kependidikan, (5) Menerapkan peraturan, tata tertib, juga sanksi yang tegas terhadap suatu perilaku kekerasan serta pelecehan yang terjadi di sekolah.Dalam sistem sosial masyarakat, sekolah merupakan tempat di mana para siswa dan siswi berkumpul untuk saling belajar berinteraksi seperti belajar bekerja sama, belajar memahami dan menerapkan norma-norma sosial yang berlaku di sekolah, belajar menghargai antara satu sama lain serta belajar dalam berbagai aspek sosial budaya kehidupan yang terjadi di masyarakat. Dalam upaya pemaksimalan karakter siswa sekolah dasar diharuskan adanya pengelolaan atau perencanaan penyajian materi pendidikan kewarganegaraan yang dilakukan oleh 
5273 Peran Pendidikan Kewarganegaraan dalam Mewujudkan Sekolah Damai di Tengah-Tengah Kehidupan Masyarakat Pluralis - Aulia Nur Jannah, Putri Salma N, Rachmi Nursifa Yahya, Dinie Anggraeni Dewi, Yayang Furi Furnamasari

DOI: https://doi.org/10.31004/basicedu.v5i6.1604

guru kelas agar proses penyampaian materi dapat tersampaikan secara efektif dan efisien agar guru maupun siswa mendapatkan manfaat dari pembelajaran pendidikan kewarganegaraan tersebut.

Oleh karena itu, guru pendidikan kewarganegaraan harus memiliki kemampuan dalam meminimalisir atau bahkan menghilangkan penekanan terhadap suatu golongan masyarakat, ras, suku, dan agama agar dapat mewujudkan keadilan dengan menggunakan berbagai metode pendekatan untuk membentuk kepribadian siswa khususnya dalam menumbuhkan sikap toleransi antar teman sebaya.

\section{DAFTAR PUSTAKA}

Aji, P. C. (2018). Peran Pkn Dalam Membentuk Karakter Kewarganegaraan Melalui Pendekatan Berbasis Nilai Di Perguruan Tinggi.

Amala Sundari, D. A. D. (2021). Urgensi Pendidikan Kewarganegaraan: Reaktualisasi Kapabilitas Berbangsa Dan Bernegara Pada Siswa Sekolah Dasar. Edukatif: Jurnal Ilmu Pendidikan, 3(2), 523-528.

Aulia, Syifa Siti, I. A. (2019). Pendidikan Kewarganegaraan Dalam Lingkup Sosio-Kultural Pendidikan NonFormal. Jurnal Civic Education: Media Kajian Pancasila Dan Kewarganegaraan, 3(1), 1-12.

Baharudin, Wahyuni, E. . (2010). Teori Belajar Dan Pembelajaran. Ar Ruzz Media.

Bilqis, F., Karina, T., \& Latipah, I. C. (2019). Peran Konselor Dalam Mewujudkan Sekolah Aman Dan Damai Bagi Siswa. Teraputik: Jurnal Bimbingan Dan Konseling, 2(3), 115-122.

Gunawan, I. (2013). "Metode Penelitian Kualitatif." Jakarta: Bumi Aksara 143

Halim, A. R., \& Mislinawati, M. (2019). Upaya Guru Dalam Menerapkan Karakter Cinta Damai Pada Siswa Sekolah Dasar Negeri 51 Kota Banda Aceh. Jurnal Ilmiah Mahasiswa Pendidikan Guru Sekolah Dasar, 4(2).

Hamid, S. (2018). Normalising Intolerance: Elections, Religion And Everyday Life In Indonesia. Centre For Indonesian Law, Islam And Society, Melburne Law School. The University Of Melbourne.

Hanum, F. (2012). Pendidikan Multikultural Dalam Pluralisme Bangsa. Lemlit Uny.

Izma, T. Yolanda, V. (2019). Peran Pendidikan Kewarganegaraan Dalam Membangun Karakter Bangsa. Jurnal Universitas Pgri Palembang.

Kaelan, M.S. Dan Zubaidi, A. (2010). Pendidikan Kewarganegaraan. Paradigma.

Mahnan Marbawi, Setiyo Iswoyo Husni Mubarok, A. M. D. S. (2020). Indikator Sekolah Damai Mencipta Generasi Penjaga Kebhinekaan "Panduan Sekolah Damai, Konsep Dan Indikator. Wahid Fondation.

Munthe, B. (2010). Desain Pembelajaran. Pustaka Insan Madani.

Murniyetti, M., Engkizar, E., \& Anwar, F. (2016). Pola Pelaksanaan Pendidikan Karakter Terhadap Siswa Sekolah Dasar. Jurnal Pendidikan Karakter, 6(2).

Parekh, B. (2017). Ethinking Multiculturalism, Cultural Diversity And Political Theory. Macmillan Education.

Putri, Ragil Dian Purnama, N. E. S. (2018). Implementasi Nilai-Nilai Karakter Kece (Komunikatif, Empatik, Cinta Damai, Energik) Di Sekolah Dasar Dalam Pemanfaatan Bonus Demografi. Prosiding Seminar Nasional Pendidikan Fisika" Motogpe.

Sofian Abdulatif, D. A. D. (2021). Peranan Pendidikan Kewarganegaraan Dalam Membina Sikap Toleransi Antar Siswa. .." Jurnal Pendidikan Dan Pengajaran Guru Sekolah Dasar (Jpp Guseda), 4(2), 103-109.

Suharyanto, A. (2013). Peranan Pendidikan Kewarganegaraan Dalam Membina Sikap Toleransi Antar Siswa. Jppuma : Jurnal Ilmu Pemerintahan Dan Sosial Politik Universitas Medan Area, 1(2), 12.

Sumaatmadja, N. (1990). Konsep Dan Eksistensi Pendidikan Umum. Ikip Bandung. 
5274 Peran Pendidikan Kewarganegaraan dalam Mewujudkan Sekolah Damai di Tengah-Tengah Kehidupan Masyarakat Pluralis - Aulia Nur Jannah, Putri Salma N, Rachmi Nursifa Yahya, Dinie Anggraeni Dewi, Yayang Furi Furnamasari

DOI: https://doi.org/10.31004/basicedu.v5i6.1604

Supriyanto, A. (2018). Upaya Untuk Meningkatkan Keberanian Berpendapat Dan Prestasi Belajar Melalui Penerapan Model Dilema Moral Mata Pelajaran Ppkn. Jurnal Bhineka Tunggal Ika: Kajian Teori Dan Praktik Pkn, 5(2), 116-122.

Tirtarahardja, U. (1994). Pengantarpendidikan. Dirjen Dikti Depdikbud.

Widiyanto, D. (2017). Pembelajaran Toleransi Dan Keragaman Dalam Pendidikan Pancasila Dan Kewarganegaraan Di Sekolah Dasar. 109-115.

Zulnuraini. (2012). Pendidikan Karakter : Konsep Implementasi, Dan Pengemabngannya Di Sekolah Dasar Di Kota Palu. Jurnal Dikdas, 1(1). 